\title{
The Effect Of Organic Fertilizers On Growth and Yield of Water Spinach (Ipomoea reptans Poir)
}

\author{
Selvia Dewi Pohan, Amrizal, Wina Dyah Puspitasari \\ Biology Department, Faculty of Mathematics and Natural Sciences, Universitas Negeri Medan
}

Article Info

Received:

26 February 2021

Accepted:

09 March 2021

Published:

10 March 2021

Competing Interest:

The authors have declared that no competing interest exists.

\section{Corresponding Author:}

Selvia Dewi Pohan,Biology Department, Faculty of Mathematics and Natural Sciences, Universitas Negeri Medan, North Sumatera, Indonesia

Email: selviadewipohan@unimed.ac.id

(C) 2021 The Authors. This is an open access article under the CC BY license.

\begin{abstract}
Water spinach (Ipomoea reptans Poir) has been identified as a nutritious vegetable with high demand in Indonesia. Besides, this plant also has been evidenced to play an important role in environmental cleaning as a phytoremediator. This study was conducted in the Green House of Biology Department, Faculty of Mathematics and Natural Sciences, Universitas Negeri Medan. The study aims to investigate the most effective type of fertilizers and the dose for water spinach's (Ipomoea reptans Poir) growth and yield. A Completely Randomized Factorial Design was applied for the experiment with two factors and three repetitions. The first factor is the type of fertilizer (chicken manure, cow manure, and compost), and the second factor is the dose of the fertilizer (1:1, 2:1, and 3:1). The parameters such as plant height, number of shoots, number of leaves, fresh weight, dry weight, leaf's total chlorophyll content, and water content were measured to evaluate plant growth and yield. The General Linear Model used SPSS 21 programs was applied to analyze the collected data. Study results revealed that cow manure increased plant growth and yield significantly with dose 2:1 as the best treatment, followed by dose 3:1. Cow manure also increased total chlorophyll content $(8.0574 \mathrm{mg}$. L-1), with the most suitable dose was 2:1 (8.2807 mg. L-1). The plant's water content tends to be high in chicken manure $(93 \%)$, and the lower water content was in cow manure with a dose of $3: 1(87.5 \%)$.
\end{abstract}

Keywords: Effect, organic fertilizers, growth, yield, water spinach (Ipomoea reptans Poir) 


\section{Introduction}

Climate change is one of the major factors that affected agricultural productivity. Several studies have been revealed regarding the effects of climate change on agricultural productivity. The forecast of climate change is still unconvinced. Besides being affected by climate change, the agriculture sector also contributes to the changes itself (Aydinalp and Cresser, 2008).

The government in many countries has supported improving agricultural productivity and implementing sustainable agricultural systems and management. The efforts such as using technology, controlling pesticide usage, avoiding environmental pollution, and relying more on biological utilization rather than chemical products have been conducted. Application continuously of inorganic fertilizers may lead to declining in soil fertility. Meanwhile, utilization of organic fertilizers confers agricultural products with high quality without damaging soil and environment equilibrium.

As mentioned in Policy Direction 2020-2030 of SDGs Indonesia, strengthening sustainable national food security becomes one strategy in the agriculture sector. To enhance mitigation for climate change, the function of the land ecosystem has to be returned as well as the forest and peat ecosystems. Several studies evidenced that using organic fertilizer effectively maintains soil fertility coincidence to enhance crop productivity. Organic fertilizer contains a high level of macro elements such as $\mathrm{N}, \mathrm{P}$, and $\mathrm{K}$.

Application of inorganic fertilizer had been conducted to increase the yield of crop production. Unfortunately, the use of inorganic fertilizer alone may cause problems to human health and the environment. The complementary use of organic and inorganic fertilizer has been recommended for sustainable crop cultivation. Combination application of organic and inorganic fertilizers had been conducted to enhance crop productivity worldwide. However, to minimize the cost of fertilizing and using renewable forms of energy, resuscitated organic manure application might have to be considered (Ayoola and Adeniran, 2006).

The use of organic material becomes a technique in organic farming. Although organic farming was initially considered very difficult, took longer, and can only be conducted on small agricultural land, awareness of the importance of maintaining health and the environment has made organic farming more widely known and increasingly demanded by the public. Some agricultural products such as organic rice, fruits, and vegetables become the biggest-selling organic foods (You and Hsieh, 2017). The high demand for these organic products has encouraged farmers to switch to organic farming, especially in urban areas and in developed countries. Therefore, it is essential to discover effective methods in organic vegetable cultivation.

Using organic and environmentally-friendly compounds in agricultural practices is satisfied globally. The crucial part of organic farming is increasing yield and quality controls nutrient balance (Abo-Sedera et al, 2016). Organic manure can provide essential elements for crop plants since many studies have been revealed the effectiveness of organic fertilizer, particularly for vegetable plants (Abo-Sedera et al, 2016; Dimouska et al, 2019; Ouda and Mahadeen, 2008; Yoldas et al, 2011). Chicken manure, cow manure, and compost are fertilizers used to improve soil amendment and vegetable crop yield. Some studies on the use of manure in vegetables conferred positive results (Iskandar, 2003; Pujisiswanto and Pangaribuan, 2008; Sepentong and Syahfari, 2014). Compost fertilizer has been proven can improve soil characteristics: increasing soil productivity and organic matter content. Compost applications can repay the use of chemical fertilizers, which harm environmental balance (Natsheh and Mousa, 2014). There are exchanges in soil's chemical characteristics before and after applying organic fertilizer, particularly in Corganic, N-total, P-total, and soil acidity.

Water spinach becomes a high-demand vegetable type in Indonesia. This plant can grow quickly in the lowlands or the highlands. Besides, this plant can also be harvested quickly, which only requires approximately 4-5 weeks. This Convolvulaceae plant is valuable, easy to cultivate, and contains enough nutrients such as carbohydrates, fats, protein, calcium, phosphorus, iron, vitamin $A$, vitamin B1, and vitamin C (Ayati, 2006). Ecologically, it also performed as a phytoremediator. Based on the study by Suchaida et al, (2015), this plant was able to absorb heavy metals such as $\mathrm{Fe}(13.9 \%)$ and $\mathrm{Al}(11 \%)$ in Lapindo mud deposits. Ratnasari et al, (2020) have proved that this plant could adsorb another heavy metal, cadmium (Cd), up to $73.59 \%$. It could accumulate $\mathrm{Cd}$ in roots, shoots, and leaves (Suhaeni and Rida, 2016).

Requirements for growing water spinach are uncomplicated. It grows appropriately without chemical fertilizers so that chemical exposures can be avoided. There have been many studies evidenced the negative impact of the use of chemical pesticides, including causing pest resistance, causing the detonation of new pest populations (resurgence), accumulation of chemical residues in the harvested products, killing of natural enemies, environmental pollution, poisoning in humans and animals, and ruin the ecosystem balance (Castillo et al, 2010).

Manure is abundant of microorganisms supporting organic material's degradation in the soil. The degradation process can optimize the transformation of the organic compound into ions. The transformation of mineral elements in the soil is related to the yield. The yield parameter commonly demonstrates the fresh weight of the plant. By giving organic fertilizer to the vegetable plant, managing the best variant, dosage, application, soil properties, and plant productivity can increase (Perdana et al, 2014). The study investigates the effect of three types of organic fertilizers with three doses on water spinach growth and yield. The best treatment will be the answer for the cultivation problem in providing proper nutrients for the plant by considering environmental safety to enhance vegetable's productivities. 


\section{Materials and Methods}

\section{A. Materials}

The materials used in this study were as follows: groundwater spinach seeds, soil, organic fertilizers (compost, chicken manure, cow manure), 80\% acetone, aquadest, etc. The equipment used in this study were as follows: $5 \mathrm{~kg}$ polybag, pesticide spray tubeholster, glass bottle, thermometer, hygrometer, $\mathrm{pH}$ indicator, mortar, glass beaker, measuring cup, drop pipette, test tube, round bottom flask, filter paper, spectrophotometer, digital camera, analytical scale, stationery, etc.

\section{B. Methods}

Experimental research using a Completely Randomized Factorial Design was conducted with two factors and three replications. The first factor was the fertilizer types, namely chicken manure (TKA), cow manure (TKS), and compost (TKO). The second factor was the dose of fertilizer (soil:manure), with ratio of $1: 1(2.5 \mathrm{~kg} /$ polybag), $2: 1(1.67 \mathrm{~kg} /$ polybag), and $3: 1(1.25 \mathrm{~kg} /$ polybag).

The research was started with the nursery process; the 1 -week old seedlings were transferred to the treatment's medium. Growth observations were carried out for six weeks. The parameters measured to determine plant growth and yield were as follows: (1) plant height; (2) leaf number/plant; (3) shoot number/plants (4) plant's fresh weight; (5) plant's dry weight; (6) plant's water content; and (7) chlorophyll content of leaves. Parameters 4 to 7 were measured at the end of the observation ( 6 weeks after cultivation). After the plant was harvested, the fresh weight was measured. The plant's dry weight measurement was carried out after added to the oven at a temperature of $80^{\circ} \mathrm{C}$ for three days until the weight was constant. Then, the dry weight has been calculated using an analytical balance.
Evaluation of chlorophyll content was conducted by extracting the plant's leaves with $80 \%$ acetone solvent. After obtaining the extraction, the absorbance value was quantified with a spectrophotometer at a wavelength of $645 \mathrm{~nm}$ and $663 \mathrm{~nm}$. Then the chlorophyll concentration of the leaves was calculated using the formula by Arnon (1949). The comparison of plant growth and yield between treatments was analyzed with the General Linear Model (SPSS 21 program). If there are differences between treatments, data were continued with Duncan's Posthoc test at $\alpha=0.05$ level.

\section{Results and Discussion}

\section{Results}

The research was carried out in a greenhouse with a daily temperature between $32^{\circ} \mathrm{C}-38^{\circ} \mathrm{C}$ and relative humidity of $42 \%-66 \%$. Observations were made up to 6 weeks after cultivation. Data on the plant height, number of leaves, and number of shots were taken once a week.

The results confirmed the plant height of water spinach was outstanding in compost treatment. Consistently, plant height increased from the first up to the fourth week (Figure 1). The difference in fertilizer dose given did not confer a significant effect on the plant's height. Compost fertilizer conferred a significant effect on the number of plant leaves, although the increase in the number of plant leaves was better on the treatment of cow manure at a dose of 2:1. However, cow manure has the most significant influence on shoot growth among two other fertilizers types, with the most significant doses being 2: 1 and 3: 1. The growth measurement results during six weeks of observation in all treatments were provided in Table 1.

Table 1. The recapitulation of water spinach's responses on the application of three types of organic fertilizer with three levels of dose.

\begin{tabular}{|c|c|c|c|c|c|c|}
\hline Treatments & $\mathrm{PH}(\mathrm{cm})$ & $\mathrm{LN}$ & $\mathrm{SN}$ & $\mathrm{FW}(\mathrm{g})$ & $\mathrm{DW}(\mathrm{g})$ & $\mathrm{CC}\left(\mathrm{mg} \cdot \mathrm{L}^{-1}\right)$ \\
\hline Chicken Manure & $39.57 \pm 3.316 \mathrm{a}$ & $15.44 \pm 4.362 \mathrm{a}$ & $2.00 \mathrm{a}$ & $6.44 \pm 2.345 \mathrm{a}$ & $0.476 \mathrm{a}$ & $7.6516 \mathrm{~b}$ \\
\hline Cow Manure & $50.64 \pm 5.187 b$ & $22.00 \pm 3.5 b$ & $2.67 \mathrm{~b}$ & $13.49 \pm 4.757 \mathrm{c}$ & $1.417 \mathrm{c}$ & $8.0574 \mathrm{c}$ \\
\hline Compost & $62.49 \pm 13.801 \mathrm{c}$ & $18.67 \pm 3.041 \mathrm{ab}$ & $2.11 \mathrm{a}$ & $10.64 \pm 2.812 \mathrm{~b}$ & $0.996 \mathrm{~b}$ & $7.2495 \mathrm{a}$ \\
\hline Dose 1:1 (soil:manure) & $54.61 \pm 18.19 \mathrm{a}$ & $16.67 \pm 5.074 \mathrm{a}$ & $1.93 \mathrm{a}$ & $7.82 \pm 3.368 \mathrm{a}$ & $0.801 \mathrm{a}$ & $7.4432 \mathrm{a}$ \\
\hline Dose 2:1 (soil:manure) & $54.42 \pm 14.17 \mathrm{a}$ & $20.22 \pm 4.438 b$ & $2.44 b$ & $11.35 \pm 4.125 b$ & $0.965 a$ & $7.8032 \mathrm{bc}$ \\
\hline Dose 3:1 (soil:manure) & $50.58 \pm 9.67 \mathrm{a}$ & $19.22 \pm 3.42 \mathrm{ab}$ & $2.11 \mathrm{~b}$ & $11.41 \pm 4.808 \mathrm{~b}$ & $1.123 \mathrm{a}$ & $7.7121 \mathrm{ab}$ \\
\hline
\end{tabular}

Description: PH: plant height; LN: leaf number; SN: shoot number; FW: fresh weight; DW: dry weight; CC: total chlorophyll content.

$V$ alues followed by the same letter shown are not significantly different at $a=0.05$ 


\section{A. Plant Height}

The compost treatments posed as the best performance based on plant heights (Figure 1), although the dose did not significantly influence. The fertilizer type has a significant impact on plant height.
The plant's height measurement results were provided in the following Table 2. The plant grew slowly in chicken manure treatment even though the dose has been increased.

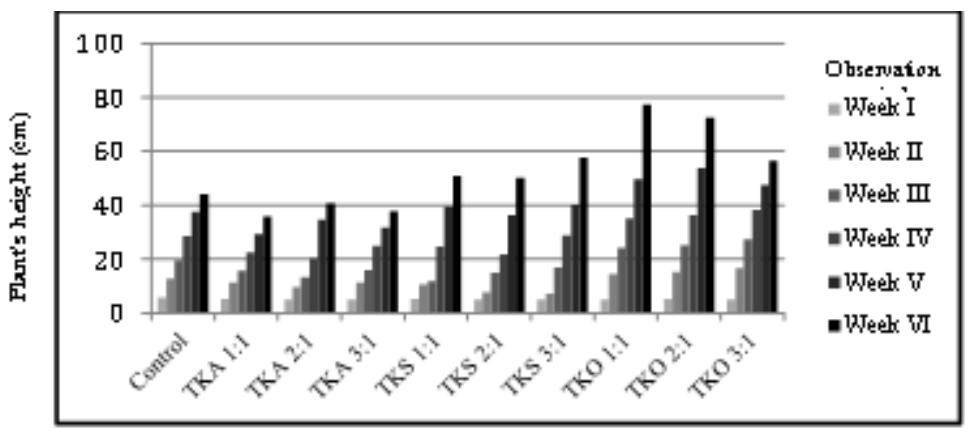

Figure 1. The growth of water spinach plants based on plant height for six weeks of observation in all treatments.

Table 2. The plant height of water spinach in three types of organic fertilizers with three doses applications.

\begin{tabular}{lcccc}
\hline \multirow{2}{*}{ Fertilizer's type/Dose } & \multicolumn{3}{c}{ Plant height $(\mathrm{cm})$} & Average \\
\cline { 2 - 4 } & $1: 1$ & $2: 1$ & $3: 1$ & $38.10 \mathrm{a}$ \\
\cline { 2 - 4 } Chicken manure & 35.73 & 40.79 & 37.75 & $52.85 \mathrm{~b}$ \\
Cow manure & 50.90 & 49.96 & 57.70 & $68.66 \mathrm{c}$ \\
Compost & 77.20 & 72.50 & 56.28 & $50.58 \mathrm{a}$ \\
\hline Average & $54.61 \mathrm{a}$ & $54.42 \mathrm{a}$ & & \\
\hline Remarks: Values followed by the same letter shown are not significantly different at $a=0.05$. &
\end{tabular}

\section{B. Shoot Number}

The use of different fertilizer types demonstrated different influences in shoot numbers. Cow manure could raise the plant's shoot number properly rather than other types of fertilizers. Increasing the dose of fertilizer did not improve the plant's shoot number, as shown in Table 3.

Table 3. The shot number of water spinach in three types of organic fertilizers with three doses applications.

\begin{tabular}{|c|c|c|c|c|}
\hline \multirow[t]{2}{*}{ Fertilizer's type/Dose } & \multicolumn{3}{|c|}{ Shoot number } & \multirow[t]{2}{*}{ Average } \\
\hline & $1: 1$ & $2: 1$ & $3: 1$ & \\
\hline Chicken manure & 1.11 & 2.22 & 2.70 & $2.01 \mathrm{a}$ \\
\hline Cow manure & 2.80 & 2.55 & 2.70 & $2.68 \mathrm{~b}$ \\
\hline Compost & 1.90 & 2.55 & 1.90 & $2.12 \mathrm{a}$ \\
\hline Average & $1.94 \mathrm{a}$ & $2.44 \mathrm{~b}$ & $2.43 b$ & \\
\hline
\end{tabular}

Remarks: Values followed by the same letter shown are not significantly different at $a=0.05$.

\section{Leaf Number}

Different types of fertilizers had different effects on leaf numbers as well. Cow manure treatment performed finest leaf number, significantly different with chicken manure but neither with compost. The dose 2:1 was more suitable to increase leaf number. 
Table 4. The leaf number of water spinach in three types of organic fertilizers with three doses applications.

\begin{tabular}{|c|c|c|c|c|}
\hline \multirow[t]{2}{*}{ Fertilizer's type/Dose } & \multicolumn{3}{|c|}{ Leaf number } & \multirow[t]{2}{*}{ Average } \\
\hline & $1: 1$ & $2: 1$ & $3: 1$ & \\
\hline Chicken manure & 10.40 & 15.70 & 20.40 & $15.50 \mathrm{a}$ \\
\hline Cow manure & 18.00 & 25.86 & 22.37 & $22.10 \mathrm{~b}$ \\
\hline Compost & 21.60 & 19.30 & 15.00 & $18.60 \mathrm{ab}$ \\
\hline Average & $16.67 \mathrm{a}$ & $20.29 \mathrm{~b}$ & $19.26 \mathrm{ab}$ & \\
\hline
\end{tabular}

Remarks: V alues followed by the same letter shown are not significantly different at $a=0.05$.

\section{Plant's Fresh Weight and Dry Weight}

The plant's fresh weight and dry weight demonstrate the yield performance of the leaf vegetable plant. The different types of fertilizer conferred different effects on the plant's weight (fresh or dry). The plant in cow manure treatment showed the best yield performances.

Table 5. The fresh weight of water spinach in three types of organic fertilizers with three doses applications.

\begin{tabular}{|c|c|c|c|c|}
\hline \multirow[t]{2}{*}{ Fertilizer's type/Dose } & \multicolumn{3}{|c|}{ Fresh weight (g) } & \multirow[t]{2}{*}{ Average } \\
\hline & $1: 1$ & $2: 1$ & $3: 1$ & \\
\hline Chicken manure & 3.76 & 6.79 & 8.78 & $6.44 \mathrm{a}$ \\
\hline Cow manure & 8.66 & 15.16 & 17.35 & $13.72 \mathrm{c}$ \\
\hline Compost & 11.75 & 12.11 & 8.08 & $10.65 b$ \\
\hline Average & $8.06 \mathrm{a}$ & $11.35 \mathrm{~b}$ & $11.4 \mathrm{~b}$ & \\
\hline
\end{tabular}

Remarks: V alues followed by the same letter shown are not significantly different at $a=0.05$.

As shown in Table 5, the plant's fresh weight was better in the smallest fertilizer concentration (but did not significantly different with dose 2:1). Differently, the plant's dry weight did not being affected by

Table 6. The dry weight of water spinach in three types of organic fertilizers with three doses applications.

\begin{tabular}{|c|c|c|c|c|}
\hline \multirow[t]{2}{*}{ Fertilizer's type/Dose } & \multicolumn{3}{|c|}{ Dry weight (g) } & \multirow[t]{2}{*}{ Average } \\
\hline & $1: 1$ & $2: 1$ & $3: 1$ & \\
\hline Chicken manure & 0.317 & 0.475 & 0.637 & $0.476 \mathrm{a}$ \\
\hline Cow manure & 0.700 & 1.384 & 2.167 & $1.417 \mathrm{c}$ \\
\hline Compost & 1.385 & 1.035 & 0.567 & $0.996 \mathrm{~b}$ \\
\hline Average & $0.800 \mathrm{a}$ & $0.965 a$ & $1.124 \mathrm{a}$ & \\
\hline
\end{tabular}

Remarks: V alues followed by the same letter shown are not significantly different at $a=0.05$.

\section{E. Total Chlorophyll Content}

The plant showed different chlorophyll content in different types of fertilizer. The highest chlorophyll content resulted in cow manure treatment with dose fertilizer's concentration. The highest dry weight resulted in cow manure treatment, followed by compost treatment (Table 6).
2:1, followed by chicken manure treatment in dose 3:1. With the compost addition, the plant's chlorophyll content posed the lowest performance, significantly different from two other types (Table 7). 
Table 7. Total chlorophyll content of water spinach in three types of organic fertilizers with three doses applications.

\begin{tabular}{|c|c|c|c|c|}
\hline \multirow[t]{2}{*}{ Fertilizer's type/Dose } & \multicolumn{3}{|c|}{ Total chlorophyll content $\left(\mathrm{mg} \cdot \mathrm{L}^{-1}\right)$} & \multirow[t]{2}{*}{ Average } \\
\hline & $1: 1$ & $2: 1$ & $3: 1$ & \\
\hline Chicken manure & 7.6209 & 7.2662 & 8.0678 & $7.6516 \mathrm{~b}$ \\
\hline Cow manure & 7.9407 & 8.2807 & 7.9507 & $8.0574 \mathrm{c}$ \\
\hline Compost & 6.7679 & 7.8626 & 7.1179 & $7.2495 \mathrm{a}$ \\
\hline Average & $7.4432 \mathrm{a}$ & $7.8032 \mathrm{bc}$ & $7.7121 \mathrm{ab}$ & \\
\hline
\end{tabular}

\section{F. Plant's Water Content}

The highest water content was provided by plants in the treatment of 2:1 chicken manure fertilizer $(92.94 \%)$, and the lowest was in cow manure 3:1

Table 8. The water content of water spinach in three types of organic fertilizers with three doses applications.

Fertilizer's type/Dose
Chicken manure

\section{Discussion}

Based on the analysis, it has been proven that compost and cow manure were two types of fertilizer that demonstrated a significant impact on plant growth. Compost could enhance the plant's height, whereas, cow manure has a significant effect on all measured parameters. Chicken manure only significantly impacted the leaves' total chlorophyll concentration. Based on these findings, it could be noted that cow manure was the most suitable type of fertilizer to improve the growth and yield of water spinach plants. This type of fertilizer could provide many nutrients, and had undergone decomposition, will quickly meet the needs of plants and provide a rapid influence on plant growth and yield.

The nutrient intake of mineral nutrients strongly influences the formation and growth of leafy plants. According to Hartatik and Setyorini (2009), chicken manure contains $2.2 \% \mathrm{~N}$ total, $22.4 \mathrm{C}$-organic, $2.9 \%$

Average treatment $(87.5 \%)$. The dose level of fertilizer did not cause a different effect on the water content of the plants (Table 8). 
Based on this study result, it has been proven that the growth of water spinach was higher by adding cow manure in the media compared to other treatments. Although chicken manure has higher nutrient content than cow manure and compost, chicken manure did not suitable for increasing plant performance. However, chicken manure is hot, lead to a quick decomposition process by microorganisms (Arifah, 2013). Therefore, its lowest dose (3: 1) shown a more good effect (in this study, it can increase total chlorophyll levels) rather than the higher levels. It means that increasing doses of manure did not guarantee that the plants will have better growth, especially if the soil factors are less supportive.

Manure could decompose into stable humus and enrich soil organic matter for a long time. However, manure required time to process mineralization and produce stable organic material by metabolizing microorganisms in the soil, to not be directly applied to plants (Pratiwi, 2013). The cow manure application proved to be very effective in increasing the leaf number, fresh weight, dry weight, and chlorophyll content. Gana (2009) found these results as well, where cow manure at a dose of 10 tons/ha increased sugarcane yield from 60 tons/ha to 70.63-76.23 tons/ha. Likewise, with the results of research Zulkarnain et al, (2013), it was known that the addition of cow manure could increase organic matters and physical properties in sugarcane's yield (up to $94.7 \%$ ).

Cow manure increased the plant's dry weight in this study. A commonly known plant's dry matter was a figure of the translocation of photosynthesis (photosynthates) to all parts of the plant (Pujisiswanto and Pangaribuan, 2008). Cow manure provides sufficient nutrients for the plant as well as for the metabolism processes. Essential elements such as $\mathrm{N}$, $\mathrm{P}$, and $\mathrm{K}$ are primarily necessary for plant metabolic processes. Based on Rutkowska et al, (2014) study, besides contributing to the accumulation of organic matter in the soil, farmyard manure also significantly influenced changes in the concentration of microelements in the soil solution. The manure application limited $\mathrm{Mn}$ and $\mathrm{Cu}$ content and increased $\mathrm{Zn}, \mathrm{B}$, and Fe mobility in soil solution.

From the beginning of observation, plant height, the number of shoots, and the number of leaves continued to increase to 6 weeks. This condition was related to the ability of organic matter in cow manure in improving soil biological properties to create a better environment for plant roots.

Compost fertilizer has a good influence on the soil's chemical properties, especially in the compost containing humus and macro elements for the soil such as $\mathrm{N}, \mathrm{P}$, and $\mathrm{K}$ as well as microelements such as $\mathrm{Ca}, \mathrm{Mg}, \mathrm{Mn}, \mathrm{Cu}, \mathrm{Fe}, \mathrm{Na}$, and $\mathrm{Zn}$. Deficiencies of microelements such as $\mathrm{B}, \mathrm{Cu}, \mathrm{Fe}, \mathrm{Mn}$, and $\mathrm{Mo}$ potentially reduced crop yield and quality (Alloway, 2008).

Based on Wasis and Fathia's (2010) study, compost fertilizer significantly affected the Gmelina Arborea Roxb growth. It significantly affected plant height (42.88\%) with a dose of $30 \mathrm{~g} / \mathrm{plant}$. The provision of compost in water spinach plants in this study significantly affected plant height, fresh weight, and dry weight (but neither on number of shoots, number of leaves, and leaf chlorophyll content). Research conducted by Zulkarnain et al, (2013) proved that the application of compost was able to increase the soil C-organic content from $0.45 \%$ to $0.93 \%$ (relatively low), increasing the total $\mathrm{N}$-content from $0.20 \%$ to $0.60 \%$ (relatively low).

Even though compost can reduce soil weight and increase soil porosity, the compost addition has not significantly increased sugarcane yield. Nitrogen is an essential element to build chlorophyll molecules as well as $\mathrm{Mg}$. If the soil can provide sufficient $\mathrm{N}$ content for the plant, it will affect the leaves' chlorophyll content. Leaf chlorophyll content gives beneficial information regarding the plant's physiological status (Gitelson et al, 2003). During the photosynthesis process, light energy is conversed by chlorophyll a and chlorophyll b to produce chemical energy. Chlorophyll content establishes photosynthetic potential and primary production and is closely connected to plant stress and senescence (Curran et al, 1990; Filella et al, 1995). A plant with good and sufficient chlorophyll content reflects it is well-growing in cultivation. In this study, water spinach has a high level of chlorophyll content, which evidenced that nutrition in the media has sufficiently provided the plant need to grow and develop.

Based on the study, it can be noted that the treatment of cow manure has the best effect on almost all parameters measured. The assumption is that cow manure nutrient content is most suitable and sufficient for the growth and yield of water spinach. Cow manure played an important role in improving soil composition and fertility. Although cow manure nutrient content is not very high, some virtues can improve porosity, permeability, soil structure, and water binding and cations in the soil.

\section{Conclusions}

According to the study results, it can be concluded that the overall treatment of types of cow manure at doses of 2: 1 and 3: 1 provided the best influences on the growth and yield of water spinach (Ipomoea reptans Poir).

\section{References}

[1] Abo-Sedera, F.A., A.S. Shams, M.H.M. Mohamed, and A.H.M. Hamoda. 2016. Effect of organic fertilizer and foliar spray with some safety compounds on growth and productivity of snap bean. Annals of Agricultural Sciences, Moshtohor. 54(1):105-118.

[2] Alloway, B.J. 2008. Micronutrient and crop production: An introduction. In: Alloway B.J. (eds) Micronutrient deficiencies in global crop production. Springer, Dordrecht.https://doi.org/10.1007/978-1-4020-6860-7_1.

[3] Arifah, S.M. 2013. Aplikasi macam dan dosis pupuk kandang pada tanaman kentang. Jurnal GAMMA. 8(2): 80-85.

[4] Arnon, D.I. 1949. Copper enzymes in isolated chloroplast, polyphenoxidase in beta vulgaris. Plant Physiology, 24:1-15.

[5] Aydinalp, C. and M.S. Cresser. 2008. The effect of global climate change on agriculture. American-Eurasian Journal of Agriculture and Environmental Sciences. 3(5):672-676. 
[6] Ayoola, O.T. and O.N. Adeniran. 2006. Influence of poultry manure and NPK fertilizer on yield and yield components of crops under different cropping systems in South-West Nigeria. African Journal of Biotechnology. 5:1336-1392.

[7] Castillo, L.E., J.J. Jimenez and M.A. Delgado. 2010 Secondary Metabolites of the Annonaceae, Solanaceae, and Meliaceae Families Used as Biological Control of Insects. Journal of Tropical and Subtropical Agroecosystems. 12: 445 462.

[8] Curran, P.J., J.L. Dungan and H.L. Gholz. 1990. Exploring the relationship between reflectance red edge and chlorophyll content in slash pine. Tree Physiology. 7:33-48.

[9] Dimouska, D., L. Mihajlov, F. Trajkova, L.K. Gudeva and I. Iljovski. 2019. The influence of organic fertilizers on the growth and yield of broccoli (Brassica oleracea var. italic). Journal of Agriculture and Plant Sciences. 17(2):25-30.

[10] Filella, I., I. Serrano, J. Serra and J. Penuelas. 1995. Evaluating wheat nitrogen status with canopy reflectance indices and discriminant analysis. Crop Science. 35:1400-1405.

[11] Gana, A.K. 2009. Evaluation of the residual effect of cattle manure combinations with inorganic fertilizer and chemical weed control on the sustainability of chewing sugarcane production at Badeggi Southern Guinea Savanna of Nigeria. Middle-East Journal of Scientific Research. 4(4).282-287.

[12] Gitelson, A.A., Y. Gritz and M.N. Merzlyak. 2003. Relationship between leaf chlorophyll content and spectral reflectance and algorithms for non-destructive chlorophyl assessment in higher plant leaves. Journal of Plant Physiology. 160:271-282.

[13] Hartatik, W. and D. Setyorini. 2009. Pengaruh pupuk organik terhadap sifat kimia tanah dan produksi tanaman padi sawah organik. Prosiding Seminar Nasional dan Dialog Sumber Daya Lahan Pertanian. Bogor (ID).21-25.

[14] Iskandar, D. 2003. Pengaruh dosis pupuk N, P, K terhadap pertumbuhan dan produksi jagung manis di lahan kering. Prosiding Seminar Teknologi untuk Negeri. Huma BPPT/ANY.

[15] Leghari, S.J., N.A., Wahocho, G.M. Laghari, A.H. Laghari, G.M. Bhabhan and K.H. Talpur. 2016. Role of nitrogen for plant growth and development: A review. Advances in Environmental Biology. 10(9):209+

[16] Natsheh, B. and S. Mousa. 2014. Effect of organic and inorganic fertilizers application on soil and cucumber (Cucumis sativa L.) plant productivity. International Journal of Agriculture and Forestry. 4(3):166-170.

[17] Ouda, B.A. and Y. Mahadeen. 2008. Effect of organic fertilizers on growth, yield, yield component, quality, and certain nutrient contents in broccoli (Brassica oleracea). International Journal of Agriculture and Biology. 10:627-632.

[18] Perdana B.S.K and S. Fairiani. 2014. The effect of application of bio stimulator and plant spacing on growth and yield of swamp cabbage (Ipomoea reptans Poir). Jurnal Produksi Tanaman. 2(6):474-483.

[19] Pratiwi, D. 2013. Pemanfaatan pupuk kandang ayam dan fungi mikoriza arbuskula untuk memperbaiki pertumbuhan bibit jeruk siam. Skripsi Departemen Agronomi dan Hortikultura Fakultas Pertanian IPB. Bogor.

[20] Pujisiswanto, H. and D. Pangaribuan. 2008. Pengaruh dosis kompos pupuk kandang sapi terhadap pertumbuhan dan produksi buah tomat. Prosiding Seminar Nasional Sains danTeknologi II Universitas Lampung.

[21] Rao, N.S. 1994. Mikroorganisme tanah dan pertumbuhan tanaman. UI Press. Jakarta.

[22] Ratnasari I.F.D., S.N. hadi., S.R. Suparto, O. Herliana and Y.R. Ahadiyat. 2020. Phytoremediation of cadmium contaminated soil using terrestrial kale (Ipomoea reptans Poir) and corncob biochar. Journal of Degraded and Mining Lands Management. 7(4):2313-2318

[23] Rutkowska, B., W. Szulc, T. Sosulski, and W. Stepien, 2014 Soil micronutrient availability to crops affected by long-term inorganic and organic fertilizer applications. Journal of Plant Soil Environment. 60(5):198-203.

[24] Sepentong and H. Syahfari. Pengaruh pupuk kandang sap dan green tonik terhadap pertumbuhan dan hasil tanaman jagung manis (Zea mays L. saccharata Sturt). Jurnal Agrifor. 13(2): 199-206
[25] Suhaeni and Y.W. Rida. 2016. Analysis of the heavy metal content of cadmium (Cd) on Ipomoea reptans Poir. Jurnal Dinamika.7(2):1-8.

[26] Syarief, S. 1989. Kesuburan dan pemupukan tanah pertanian. Pustaka Buana. Bandung.

[27] Suchaida, A., K. P. Wicaksono and A. Suyanto. 2015. Tanaman kangkung darat (Ipomoea reptans Poir) sebagai fitoremediator lumpur Sidoarjo. Jurnal Produksi Tanaman. 3(6): 442-449.

[28] Wasis, B. and Fathia N. 2010. Pengaruh pupuk NPK dan kompos terhadap pertumbuhan semai Gmelina (Gmelina arborea Roxb.) pada media tanah bekas tambang emas (Tailing). Jurnal Ilmu Pertanian Indonesia. 16(2): 123-129.

[29] Yoldas, F., S. Ceylan, N. Mordogan and B.C. Esetlili. 2011. Effect of organic and inorganic fertilizers on yield and mineral content of onion (Allium cepa L.). African Journal of Biotechnology. 10(55):11488-11492.

[30] You, P.S. and Y.C. Hsieh. 2017. A computational approach for crop production of organic vegetables. Computers and Electronics in Agriculture. 134:33-42.

[31] Zulkarnain, M., Prasetya B., and Soemarno. 2013. Pengaruh kompos, pupuk kandang, dan custom-bio terhadap sifat tanah, pertumbuhan dan hasil tebu (Saccharum officinarum L.) pada entisol di kebun Ngrangkah-Pawon, Kediri. Indonesian Green Technology Journal. 2(1):45-53. 